\title{
Morphology and Growth in Seedlings of Several C4, Perennial Grasses
}

\section{P.I. COYNE AND J.A. BRADFORD}

\section{Abstract}

Establishment of forage grasses depends upon their ability to compete for resources in the critical seedling establishment phase. Desirable native grass species are generally considered to be more difficult to establish from seed than the introduced Old World bluestems (Bothriochloa spp.), although comparative data are generally lacking. This study compared the responses of morphological attributes commonly associated with seedling vigor and some growth parameters in 17 perennial, $C 4$ grasses including 5 native and 12 Old World bluestems. Plants were grown in a greenhouse under well-watered and limited watering regimes. The objective was to document differences in morphology and growth among these grasses from emergence through 7 weeks post emergence. The Bothriochloa species generally rated higher than the native species in morphological characters commonly associated with seedling vigor. The exotics produced as much or more biomass and had more leaf area per plant, more tillers, and leaves per tiller than the natives. Although the native grasses produced less leaf area, the cost of these leaves in terms of biomass per unit area was higher than in the introduced grasses. The natives tended to partition relatively more biomass aboveground and more of this to leaves, rather than sheaths plus stems, than the Old World bluestems. However, partitioning of total plant biomass among roots, sheaths plus stems, and leaf blades was remarkably insensitive to water stress in all entries. Approximately one-third of total biomass was partitioned among leaf blades, sheaths plus stems, and roots, respectively, with sheaths+stems tending to be a slightly smaller fraction than the other 2 components. Recurring water stress cycles reduced most parameters significantly and generally accentuated the normal ontogenetic decline in relative growth and unit rates. Across all entries, total plant biomass and leaf blade area were reduced over $40 \%$ by a limited watering regime. Although water stress reduced the size of the assimilatory surface, the remaining leaves were more efficient in the production of new biomass. This response correlated with an increase in specific leaf weight under water stress.

Successful establishment of forage grasses from seed depends on numerous environmental factors (see Vallentine 1980) which interact with the plant's genetic component during germination, emergence, and post-emergence growth. Plant vulnerability to environmental stresses is particularly high during seedling establishment because of limited food reserves (Johnson 1984) resulting from small seed size and limited photosynthetic capacity. The amount of food reserves stored in the endosperm is an important factor related to establishment potential (Davies 1967). Also contributing to this vulnerability is the lack of a well-developed root system. Frequently, competitive advantages gained during the seedling stage are maintained in the mature plant stage (Johnson 1984).

Variability in establishment success among species and genotypes within species is common knowledge, and high success is often associated with rapid germination, rapid root and top growth, a robust growth habit, and resistance to stress (McKell 1972). These traits are collectively referred to as seedling vigor. Numerous techniques for assessing seedling vigor have been developed (reviewed by Whalley and McKell 1973) and much effort has been expended to enhance vigor in forage plant germplasm (Kneebone 1972).

Thirty years of research have shown that selections from the

Authors are plant physiologists, USDA-ARS, Southern Plains Range Research Authors are plant physiologists, USDA-ARS, Sout
Station, 2000-18th Street, Woodward, Okla. 73801.

C.L. Dewald provided the plant materials used in this study. Tom Popham and George Hilton are acknowledged for their assistance with the statistical analyses.

Manuscript accepted March 13, 1985. genus Bothriochloa (Asiatic or Old World bluestems) can contribute significantly to beef production and soil conservation in the Southern Great Plains (Sims and Dewald 1982). The Old World bluestems have been found to exhibit relatively high seedling vigor at Woodward, Okla. in comparison with native species (C.L. Dewald, pers. comm.). Harlan et al. (1958) noted that ecologically, the Old World bluestems are best fitted to some stage of secondary succession and that they tend to increase under grazing pressure. They also noted that these grasses reproduce freely by seed, tend to be somewhat weedy, and are generally easily established in plantings. Experience has shown that establishment of stands of climax, decreaser species in the Southern Plains usually requires 2 growing seasons while only 1 is required to establish the Old World bluestems.

Of the 3 phases of seedling establishment (germination, emergence, post-emergence growth), it was felt that a manager would have least control over the last phase since high quality seed, proper seedbed preparation, and timing of planting with periods of soil moisture sufficient to ensure germination would reduce the risk associated with phases 1 and 2 . Therefore, phase 3 was isolated for study. The objective of the study was to determine differences in morphology and growth behavior among 5 native and 12 Old World bluestem perennial forage grasses from emergence through 12 weeks post emergence under near optimum conditions which could be used as indices of comparative performance potential. Because post-emergence failure is frequently associated with drought stress (Vallentine 1980, Whalley and McKell 1973) and because drought conditions can be prevalent during the normal period for establishing warm-season grasses, a suboptimal soil water treatment was included to assess relative departure of the measured parameters from potential.

\section{Materials and Methods}

\section{Plant Materials and Culture}

Seventeen perennial, warm-season grasses, including 5 native and 12 exotic Old World bluestems, were included in this study (Table 1). Woodward sand bluestem is a leafy grass of medium height with good seed production characteristics. Hachita blue grama is a relatively tall and productive selection compared to blue grama selections in general. Two switchgrass varieties were included: one is a robust upland type (Caddo), and the other (Kanlow) is adapted to lowland sites. Western indiangrass is an experimental strain selected for ease of establishment and it has low dormancy and rapid emergence compared to other indiangrass cultivars such as Cheyenne and Osage.

The Old World bluestems included 3 species. B. caucasica and $B$. intermedia have secondarily branched inflorescences, $B$. ischaemum does not. $B$. caucasica has a relatively small crown diameter (basal spread) compared to the other 2 species. ${ }^{\circ} B$. caucasica, $B$. intermedia var. indica and $B$. ischaemum var. ischaemum exhibit early seed maturity compared to $B$. intermedia var. montana. A gradation of leaf widths is present in these grasses. Wide-leaf types include $B$. intermedia var. montana, medium-leaf types include $B$. caucasica and $B$. ischaemum var. ischaemum, while $B$. intermedia var. indica is composed of narrow-leaf types. WW-477 is an introgression between the $B$. intermedia and $B$. ischaemum and has many characteristics in common with King Ranch bluestem ( $B$. ischaemum). WW-Spar bluestem, WW-535, and WW-604 are 3 of 30 yellow bluestem strains blended together to make 'Plains' bluestem (Taliaferro et al. 1972).

Potential variability in post-emergence seedling growth result- 
Table 1. Identification of plant materials and seed weight.

\begin{tabular}{|c|c|c|c|c|c|c|}
\hline \multirow[b]{2}{*}{ Entry } & \multirow[b]{2}{*}{ Scientific name } & \multirow[b]{2}{*}{ Cultivar/Accession } & \multirow{2}{*}{$\begin{array}{l}\text { Country } \\
\text { of Origin }\end{array}$} & \multirow{2}{*}{$\begin{array}{c}\text { Air-valve } \\
\text { settings }<1>\end{array}$} & \multicolumn{2}{|c|}{-Seed Size- } \\
\hline & & & & & Mean $\langle 2\rangle$ & SD \\
\hline \multicolumn{4}{|c|}{ Native Species: } & (degrees) & \multicolumn{2}{|c|}{ - } \\
\hline 1 & Andropogon hallii & Woodward sand bluestem & U.S.A. & $45-55$ & 0.2558 & 0.0116 \\
\hline 2 & Panicum virgatum & Caddo switchgrass & $"$ & $45-50$ & 0.2047 & 0.0024 \\
\hline 3 & " & Kanlow switchgrass & $"$ & $"$ & 0.1205 & 0.0038 \\
\hline 4 & Sorghastrum nutans & $\begin{array}{l}\text { WW-Western indiangrass } \\
\text { (Woodward experimental) }\end{array}$ & $"$ & $"$ & 0.1512 & 0.0020 \\
\hline 5 & Bouteloua gracilis & Hachita blue grama & $"$ & $25-30$ & 0.0554 & 0.0016 \\
\hline \multicolumn{7}{|c|}{ Old World Bluestems (Bothriochloa spp.): } \\
\hline 6 & B. caucasica & Caucasian bluestem, WW- 442 & U.S.S.R. & $30-35$ & 0.0568 & 0.0024 \\
\hline 7 & " & Caucasian bluestem, WW-765 & $"$ & $"$ & 0.0530 & 0.0005 \\
\hline 8 & B. intermedia var. indica & WW-517 & Pakistan & $\cdots$ & 0.0484 & 0.0023 \\
\hline 9 & " & WW-811 & $"$ & $"$ & 0.0420 & 0.0006 \\
\hline 10 & $"$ & WW-822 & $"$ & $"$ & 0.0532 & 0.0011 \\
\hline 11 & var. montana & WW-857 & $"$ & $"$ & 0.0366 & 0.0005 \\
\hline 12 & 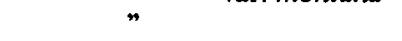 & WW-886 & $\boldsymbol{}$ & $"$ & 0.0353 & 0.0005 \\
\hline 13 & B. ischaemum var. ischaemum & Ganada bluestem & Turkey & $"$ & 0.0457 & 0.0004 \\
\hline 14 & " & WW-Spar bluestem & Pakistan & " & 0.0416 & 0.0006 \\
\hline 15 & $"$ & WW-535 & Afghanistan & $"$ & 0.0515 & 0.0011 \\
\hline 16 & $n$ & WW-604 & Pakistan & $"$ & 0.0525 & 0.0010 \\
\hline 17 & var. songarica & $W W-477$ & China & $"$ & 0.0431 & 0.0018 \\
\hline
\end{tabular}

$\langle 1>$ Refers to pneumatic air separator settings. The air flow and density of retained seed are proportional to the setting.

$<2>$ Mean weight per 100 seeds based on three lots of 100 seeds.

ing from differences in seed size (Kneebone 1972, Whalley and McKell 1973) was reduced by grading the seed lots with a pneumatic air separator. An air-valve setting of 30 to 35 degrees was used for all Old World bluestems. The smaller seed of blue grama required a lower setting and the larger seed of the remaining native species required a higher setting to obtain a representative sample of high quality seed. Air-valve settings and the mean weight per 100 seeds are given in Table 1 . The Old World bluestems are highly apomictic (Harlan et al. 1958) and each of the plants in this study within an entry are considered to be the same genotype.

Seeds were germinated on blotter paper moistened with distilled water containing Thiram (tetramethylthiuram disulfide, $4.8 \mathrm{~g}$ ai $1^{-1}$ ) to control fungal growth. Initial wetting of the blotters was staggered during the period 31 Oct. to 4 Nov. 1983 to allow for differences in germination rates among entries based on previous germination pilot studies. Uniformly germinated seeds, with both radicle and coleoptile showing, were transplanted (coleoptile just penetrating the soil surface) to 2 treatments (wet, dry) as defined below on 7 and 8 Nov. 1983, respectively.

The rooting medium was a Pratt loamy sand (thermic Psammentic Haplustalfs) collected from the surface $50 \mathrm{~mm}$ of fallow wheat ground, screened, mixed, and sterilized with methyl bromide (bromomethane). Soil was placed in tapered cells having a top diameter of $25 \mathrm{~mm}$, a bottom diameter of $18 \mathrm{~mm}$, a depth of 150 $\mathrm{mm}$, and a volume of $68 \mathrm{ml}$. The soil in each cell was initially saturated with water containing $100 \mathrm{mg} \mathrm{P}^{-1}$ as $\mathrm{Ca}\left(\mathrm{H}_{2} \mathrm{PO}_{4}\right)_{2}$ and allowed to drain. A single seedling was planted in each cell and the cells were placed in racks ( 20 by 10 cells) on a greenhouse bench and arranged in a randomized complete block design with 4 blocks for each of the 2 treatments. Each block consisted of either 3 racks (wet) or 2 racks (dry) of uniformly emerged seedlings. Seed lots from some entries had poor or slow germination, making it necessary to delete 1 rack per block from the dry treatment.

\section{Growing Conditions}

Watering was by surface application using overlapping, finespray nozzles with a discharge height of about $45 \mathrm{~cm}$ above the soil surface. During the first week following transplanting, fungicide

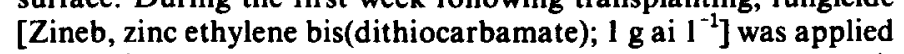
once daily through the watering system. Throughout the experiment, soil fertility was maintained by applying half-strength Hoag- land's solution (minus P) 4 times weekly through the watering system. The wet treatment was watered twice daily to approximately field capacity. The dry treatment was watered in the same manner for the first 8 days following transplanting, after which water was withheld until all entries were clearly wilted (1.5 to 2 days) and then the cells were watered to near field capacity. Supplemental lighting was provided for 14 hours each day by $400 \mathrm{~W}$ high pressure sodium lamps located $1 \mathrm{~m}$ above the tops of the cells. Photosynthetic photon flux densities in the absence of sunlight were about $300 \mu \mathrm{mol} \mathrm{m}^{-2} \mathrm{~s}^{-1}$ at the soil surface and 500 at $0.5 \mathrm{~m}$ above the soil surface. Midday values (sunlight plus lamps) exceeded $2000 \mu \mathrm{mol} \mathrm{m}^{-2} \mathrm{~s}^{-1}$. Mean photoperiod air temperature and relative humidity, as measured by hygrothermograph, were $26.4 \pm 2.4^{\circ} \mathrm{C}$ and $41.6 \pm 5.9 \%$, respectively. Mean dark temperature and humidity were $23.4 \pm 2.3{ }^{\circ} \mathrm{C}$ and $41.4 \pm 4.9 \%$, respectively.

Table 2. List of symbols, definitions and units.

\begin{tabular}{|c|c|}
\hline \multicolumn{2}{|c|}{ Tissue fraction designators $(x)$ : } \\
\hline b & Leaf blade \\
\hline ss & Leaf sheaths plus enclosed stems \\
\hline s & aboveground $=\mathrm{b}+\mathrm{ss}$ (shoots) \\
\hline $\mathbf{r}$ & belowground (roots) \\
\hline p & all fractions combined $=b+s s+r=s+r$ (plant total) \\
\hline \multicolumn{2}{|c|}{ Measured Parameters: } \\
\hline & Leaf blade area $\left(\mathrm{cm}^{2}\right.$ plant $\left.{ }^{-1}\right)$ \\
\hline Wx & Biomass of tissue fraction " $x$ " ( $\left(\mathrm{g}\right.$ plant $\left.^{-1}\right)$ \\
\hline t & Time in days (d) \\
\hline \multicolumn{2}{|c|}{ Calculated Parameters: } \\
\hline \multicolumn{2}{|r|}{ SLW Specific leaf weight $\left(\mathrm{g} \mathrm{m}^{-2}\right)=(\mathrm{Wb} / \mathrm{Ab}) \times 10000$} \\
\hline \multicolumn{2}{|r|}{ Derived Growth Parameters (after Hunt and Parsons, 1974): } \\
\hline$\overline{\mathbf{R x}}$ & $\begin{array}{l}\text { Relative growth rate of biomass where " } x "=\text { tissue fraction } s, r \text {, or } p \\
\qquad\left(g^{-1} d^{-d}\right)=(1 / W x)(d W x / d t)\end{array}$ \\
\hline $\mathbf{R} \mathbf{b}$ & $\begin{array}{l}\text { Relative growth rate of leaf blade area }\left(\mathrm{m}^{2} \mathrm{~m}^{-2} \mathrm{~d}^{-1}\right)=(1 / \mathrm{Ab}) \\
(\mathrm{dAb} / \mathrm{dt})\end{array}$ \\
\hline $\mathbf{F}$ & Leaf area rato $\left(\mathrm{m}^{2} \mathrm{~kg}^{-1}\right)=(\mathrm{Ab} / \mathrm{Wp}) \times 0.1$ \\
\hline $\mathbf{E b}$ & Unit leaf blade area rate $\left(\mathrm{g} \mathrm{m}^{-2} \mathrm{~d}^{-1}\right)=(1 / \mathrm{Ab})(\mathrm{dWp} / \mathrm{dt}) \times 10000$ \\
\hline
\end{tabular}

Note: When used as a unit, $d$ is the SI designation for day; when used as a parameter prefix, $d$ means derivative of the parameter. 


\section{Sample Collection and Processing}

Plants from the wet treatment were harvested beginning 14 days after transplanting (21 Nov. 1983) and thereafter on 28 Nov., 5 Dec., 12 Dec., 19 Dec., and 28 Dec. 1983. Plants from the dry treatment were harvested on the same schedule, but 1 day later. The 4 center cells of each entry row in a block of the wet treatment or the 2 center cells of the dry treatment were removed from the racks for processing. The cells removed on a given date were replaced by rotating cells from the outer ends (half from each end) of a row just inside the border row and moving the border plants inward. This scheme was an attempt to maintain a closed canopy and to minimize border effects.

Prior to harvesting the plants, the average number of tillers per plant, the average number of leaf blades (lamina) per plant, and the average maximum extended height (soil surface to tip of longest leaf) were recorded. Plants were severed at the soil surface and separated into leaf blades and leaf sheaths plus enclosed stems. The projected areas of the blades were measured by leaf area meter. The entire soil volume and the 2 aboveground fractions were frozen separately until further processing. Root samples were subsequently thawed and separated from the soil by spraying with water in a container having a submerged, screened bottom. All tissue fractions were lyophilized and weighed to determine biomass. Root biomass was calculated on an ash-free basis. Biomass from the 2 or 4 plants within a block was bulked by plant tissue fraction and sample date.

\section{Data Analysis}

The analysis of variance for the morphological parameters followed the procedures for a split-plot design with harvest date as the subplot factor (Steel and Torrie 1980). Plant species or accessions (hereafter called entries) means were separated by Duncan's multiple range test (Duncan 1955). Growth parameters (Table 2) were derived by regression using the plant growth analysis procedures described by Hunt and Parsons (1981). Differences in instantaneous relative growth rates and rates of change in relative growth rate over time (slopes) among entries were determined by pooling the residual sums of squares and calculating a least significant difference. Differences among entries for leaf area ratios and unit leaf rates involved covariance terms and were determine by calculating a least significant difference based on complex estimates of variance (Satterthwaite 1946, Steel and Torrie 1980). Similarities in entry ranking between treatments were estimated by Spearman's coefficient $\left(r_{s}\right)$ of rank correlation (Steel and Torrie 1980). In references to shifts in rank by greater than 3 positions which follow, the choice of three was arbitrary.

\section{Results and Discussion}

The analysis of variance for production and morphological attributes presented below showed that all main effects (entries, treatments, dates) were highly significant $(P<0.01)$. Significant interactions were limited to entries $X$ dates and treatments $X$ dates. The former was related to relative differences in rates of development. Some entries ranked high for the early harvest dates but low

Table 3. Entry group means for selected production and morphological parameters $<1>$.

\begin{tabular}{|c|c|c|c|c|c|c|}
\hline Parameter & Treat. & Native $<2>$ & B. caucasica & Groups-antermedia & B. ischaemum & $\begin{array}{l}\text { Grand } \\
\text { mean }<3>\end{array}$ \\
\hline $\begin{array}{l}\text { Total plant biomass, } \\
\text { Wp (g/plant) }\end{array}$ & $\begin{array}{c}\text { Wet } \\
\text { Dry } \\
\text { Dry/Wet }\end{array}$ & $\begin{array}{l}0.1868 \mathrm{c} \\
*_{0} 0.1104 \mathrm{~b} \\
0.59\end{array}$ & $\begin{array}{l}0.2879 \mathrm{a} \\
* 0.1110 \mathrm{~b} \\
0.39\end{array}$ & $\begin{array}{c}0.2457 \mathrm{~b} \\
*^{*} 0.1417 \mathrm{a} \\
0.58\end{array}$ & $\begin{array}{l}0.2273 \mathrm{~b} \\
* 0.1376 \mathrm{a} \\
0.61\end{array}$ & $\begin{array}{c}0.2271 \\
* 0.1283 \\
0.58\end{array}$ \\
\hline $\begin{array}{l}\text { Shoot/total plant } \\
\text { biomass (Ws/Wp) }\end{array}$ & $\begin{array}{c}\text { Wet } \\
\text { Dry } \\
\text { Dry/Wet }\end{array}$ & $\begin{array}{l}0.69 \mathrm{a} \\
0.70 \mathrm{a} \\
1.01\end{array}$ & $\begin{array}{l}0.71 \mathrm{a} \\
0.71 \mathrm{a} \\
1.00\end{array}$ & $\begin{array}{l}0.66 \mathrm{~b} \\
0.69 \mathrm{a} \\
1.05\end{array}$ & $\begin{array}{l}0.65 b \\
0.66 b \\
1.02\end{array}$ & $\begin{array}{r}0.67 \\
* 0.68 \\
1.02\end{array}$ \\
\hline $\begin{array}{l}\text { Leaf blade/ shoot } \\
\text { biomass (Wb/Ws) }\end{array}$ & $\begin{array}{c}\text { Wet } \\
\text { Dry } \\
\text { Dry } / \text { Wet }\end{array}$ & $\begin{array}{l}0.61 \mathrm{a} \\
0.60 \mathrm{a} \\
0.98\end{array}$ & $\begin{array}{l}0.55 \mathrm{c} \\
0.56 \mathrm{~b} \\
1.02\end{array}$ & $\begin{array}{l}0.58 \mathrm{~b} \\
0.56 \mathrm{~b} \\
0.97\end{array}$ & $\begin{array}{l}0.59 b \\
0.58 b \\
0.98\end{array}$ & $\begin{array}{r}0.59 \\
* 0.58 \\
0.98\end{array}$ \\
\hline Tillers (No./plant) & $\begin{array}{c}\text { Wet } \\
\text { Dry } \\
\text { Dry/Wet }\end{array}$ & $\begin{array}{r}1.4 \mathrm{~d} \\
* 1.2 \mathrm{~d} \\
0.86\end{array}$ & $\begin{array}{r}2.5 \mathrm{c} \\
* 1.7 \mathrm{c} \\
0.68\end{array}$ & $\begin{array}{l}2.8 \mathrm{~b} \\
2.6 \mathrm{~b} \\
0.93\end{array}$ & $\begin{array}{l}3.1 \mathrm{a} \\
3.0 \mathrm{a} \\
0.97\end{array}$ & $\begin{array}{l}2.6 \\
* 2.3 \\
0.89\end{array}$ \\
\hline Leaves (No./plant) & $\begin{array}{c}\text { Wet } \\
\text { Dry } \\
\text { Dry/Wet }\end{array}$ & $\begin{array}{r}4.9 \mathrm{~d} \\
* 3.9 \mathrm{~d} \\
0.80\end{array}$ & $\begin{array}{r}8.5 \mathrm{c} \\
* 5.4 \mathrm{c} \\
0.64\end{array}$ & $\begin{array}{r}9.9 \mathrm{~b} \\
* 7.8 \mathrm{~b} \\
0.79\end{array}$ & $\begin{array}{r}11.7 \mathrm{a} \\
* 9.2 \mathrm{a} \\
0.79\end{array}$ & $\begin{array}{c}9.1 \\
* 7.0 \\
0.78\end{array}$ \\
\hline Leaves/Tiller & $\begin{array}{c}\text { Wet } \\
\text { Dry } \\
\text { Dry/Wet }\end{array}$ & $\begin{array}{l}3.56 \mathrm{~b} \\
3.48 \mathrm{a} \\
0.98\end{array}$ & $\begin{array}{l}3.53 \mathrm{~b} \\
3.27 \mathrm{~b} \\
0.93\end{array}$ & $\begin{array}{c}3.62 \mathrm{ab} \\
* 3.18 \mathrm{~b} \\
0.88\end{array}$ & $\begin{array}{c}3.88 \mathrm{a} \\
\begin{array}{c}3.29 \mathrm{ab} \\
0.85\end{array}\end{array}$ & $\begin{array}{r}3.63 \\
* 3.28 \\
0.90\end{array}$ \\
\hline Leaf area $\left(\mathrm{cm}^{2} /\right.$ plant $)$ & $\begin{array}{c}\text { Wet } \\
\text { Dry } \\
\text { Dry/Wet }\end{array}$ & $\begin{array}{r}12.1 \mathrm{c} \\
7.4 \mathrm{~b} \\
0.61\end{array}$ & $\begin{array}{l}20.8 \mathrm{a} \\
* 8.7 \mathrm{ab} \\
0.42\end{array}$ & $\begin{array}{r}16.9 \mathrm{~b} \\
* 10.2 \mathrm{a} \\
0.60\end{array}$ & $\begin{array}{l}17.8 \mathrm{ab} \\
+9.7 \mathrm{a} \\
0.55\end{array}$ & $\begin{array}{c}16.1 \\
* 9.0 \\
0.57\end{array}$ \\
\hline Leaf size $\left(\mathrm{cm}^{2} /\right.$ leaf $)$ & $\begin{array}{c}\text { Wet } \\
\text { Dry } \\
\text { Dry/Wet }\end{array}$ & $\begin{array}{l}2.5 \mathrm{a} \\
2.1 \mathrm{a} \\
0.84\end{array}$ & $\begin{array}{r}2.2 \mathrm{~b} \\
* 1.5 \mathrm{~b} \\
0.68\end{array}$ & $\begin{array}{l}1.6 \mathrm{c} \\
1.3 \mathrm{c} \\
0.81\end{array}$ & $\begin{array}{r}1.3 \mathrm{c} \\
* 1.0 \mathrm{~d} \\
0.77\end{array}$ & $\begin{array}{c}1.8 \\
* 1.4 \\
0.78\end{array}$ \\
\hline Height (cm) & $\begin{array}{c}\text { Wet } \\
\text { Dry } \\
\text { Dry/Wet }\end{array}$ & $\begin{array}{r}24.3 \mathrm{~b} \\
* 19.6 \mathrm{a} \\
0.81\end{array}$ & $\begin{array}{c}26.8 \mathrm{a} \\
* 17.6 \mathrm{bc} \\
0.66\end{array}$ & $\begin{array}{c}23.6 \mathrm{~b} \\
18.7 \mathrm{ab} \\
0.79\end{array}$ & $\begin{array}{r}21.2 \mathrm{c} \\
* 16.6 \mathrm{c} \\
0.78\end{array}$ & $\begin{array}{r}24.1 \\
* 18.9 \\
0.78\end{array}$ \\
\hline $\begin{array}{l}\text { Specific leaf weight } \\
\left(\mathrm{g} / \mathrm{m}^{2}\right)\end{array}$ & $\begin{array}{c}\text { Wet } \\
\text { Dry } \\
\text { Dry/Wet }\end{array}$ & $\begin{array}{r}53.8 \mathrm{a} \\
55.7 \mathrm{a} \\
1.04\end{array}$ & $\begin{array}{c}43.0 \mathrm{bc} \\
44.3 \mathrm{~b} \\
1.03\end{array}$ & $\begin{array}{r}45.6 \mathrm{~b} \\
47.4 \mathrm{~b} \\
1.04\end{array}$ & $\begin{array}{r}41.2 \mathrm{c} \\
* 46.1 \mathrm{~b} \\
1.12\end{array}$ & $\begin{array}{c}47.2 \\
* 50.0 \\
1.06\end{array}$ \\
\hline
\end{tabular}

$<1>$ Group means within a row not followed by a common letter and treatments within a parameter and entry group marked by an asterisk are significantly different $1 P<0.05$ ).

$<2>$ The native group means included only the four tall grasses and not blue grama.

$<3>$ The grand means included all 17 entries. 
at the end of the sampling period and some conversely so that mean values were similar. The interaction of treatment with dates was a result of continual divergence between the 2 treatments with time. Both treatments were similar at the first sampling date because both treatments received similar amounts of water for the first 8 days after transplanting. However, at each succeeding harvest, water stress effects accumulated causing the divergence between treatments and hence the interaction. Therefore, entry differences within and between treatments will be emphasized in this presentation. Comparisons will also be made among entry groups and will be referenced as 'natives' (includes only the 4 tall grasses and not the short grass blue grama), 'Bca' (B. caucasica), 'Bin' ( $B$. intermedia), and 'Bis' (B. ischaemum). Symbols and units are defined in Table 2 and will not be redefined in the following discussion. In figures 1-6, normalized values on the abscissa are the actual values for each entry, as shown on the ordinate, divided by the maximum value.

\section{Biomass Production and Partitioning}

Mean total plant biomass production for 6 harvest dates, ranging from 14 to 51 days post emergence, varied over two-fold among the 17 entries in both wet and dry treatments (Fig. 1).

\begin{tabular}{|c|c|c|c|c|}
\hline & & WET TREATMENT & & DRY/WET \\
\hline ENIRI: & a 2 enent & SHERTWE + STEMS LEA MLADES & & \\
\hline OWB (WW-922) & 0.3114 & 0.33 & a & 0.59 \\
\hline CAUCASIAN (WW-765) & 0.3075 & D.SID & a & D. 36 \\
\hline OWB $(W W-517)$ & 0.2767 & 0.32 & & 0.55 \\
\hline OWB $(W W-4>7)$ & 0.2699 & 0.38 & & 0.58 \\
\hline CAUCASIRN (WW-442) & 0.2603 & [0.3! & & 0.41 \\
\hline OWB (WW-535) & 0.2524 & $b c d$ & & 0.60 \\
\hline KANLOH SWITCHGRASS & 0.2406 & [0.35 cde & & 0.54 \\
\hline WW-SPAR OWB & 0.2365 & 0.41 & & 0.54 \\
\hline CADDO SWITCHGRASS & 0.2266 & D.3E & & 0.65 \\
\hline OWB (WW-896) & 0.2228 & {$[0 . \overline{33}$} & & 8.52 \\
\hline OWB (WW-857) & 0.2192 & 0.33 & & 0.59 \\
\hline OWB (WW-811) & d. 1985 & 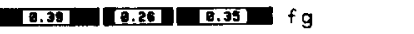 & & 0.65 \\
\hline OWB (WW-604) & D. 1972 & [0.23] $[0.35$ & & 0.56 \\
\hline GPNADA OWB & 0.1807 & Q.33 $\mathrm{g}$ & & 0.68 \\
\hline HACHITA BLUEGRAMA & 0.1718 & $0.31][0.20][8.43] \mathrm{gh}$ & & 8.71 \\
\hline WW SFNU GLUESTEM & D. 2461 & $0.34[0.27] 0.39 \mathrm{hi}$ & & 0.52 \\
\hline WESTERN INDIANGRASS & 50.1341 & 0.205 .220 .40 & & 0.67 \\
\hline & 0. & 0.5 & 1.0 & \\
\hline $\begin{array}{l}\text { HET TREATMENT MERN- } \\
\text { DRY/WET RATIO MERN- }\end{array}$ & $\begin{array}{l}0.227 ! \\
0.58\end{array}$ & ED PLANT BIOMASS & & \\
\hline
\end{tabular}

\begin{tabular}{|c|c|c|c|c|}
\hline \multirow[b]{2}{*}{ ENTRY: } & \multirow[b]{2}{*}{ a $\leq$ IIant } & DRY TREATMENT & \multicolumn{2}{|r|}{ HET,DRY } \\
\hline & & SHERTHE + STEHS LEF MADES & \multirow{3}{*}{$\mathbf{a}$} & \multirow[b]{2}{*}{1.70} \\
\hline OWB (WW-822) & B. 1831 & 0.34 & & \\
\hline OWB (WW-4>P) & 0.1576 & $a, 39$ & & 1.71 \\
\hline OWB $(W W-517)$ & 0.1518 & 0.35 & & 1.83 \\
\hline OWB (WW-535) & 0.1502 & 0.36 & & 1.60 \\
\hline CADDO SWITCHGRASS & 0.1463 & - 8.30 & & 1.55 \\
\hline OWB (WW-6B4) & 0.1318 & bcde & & 1.51 \\
\hline OWB (WW-811) & 0. 1295 & bede & & 1.53 \\
\hline KANLOW SWITCHGRASS & g. 1295 & bode & & 1.86 \\
\hline OWB (WW-857) & D. 1286 & bcde & & 1.70 \\
\hline WW-SPAR OWB & D. 1274 & bede & & 1.86 \\
\hline GANADA OWB & D. 1220 & 0.39 & & 1.48 \\
\hline HACHITA BLUEGRAMA & 0.1214 & $0.20] 0.26$ & & 1.42 \\
\hline OWB (WW-886) & D. 1162 & [.2] & & 1.92 \\
\hline CRUCASIAN (WW-765) & D. 1116 & 0.25 & & 2.75 \\
\hline CAUCASIAN (WW-442) & อ. 1103 & 0.20 & & 2.43 \\
\hline WESTERN INDIANGRASS & 50.0894 & {$[0.37[0.24] 0.39] \mathrm{fg}$} & & 1.58 \\
\hline \multirow[t]{2}{*}{ WW SAND BLUESTEM } & 0.0764 & $0.300 .27,0.30 \mathrm{~g}$ & & 1.91 \\
\hline & D & D. 5 & 1.0 & \\
\hline $\begin{array}{l}\text { DRY TREATMENT MEAN= } \\
\text { WET/DRY RATIO MEAN= } 1\end{array}$ & $\begin{array}{l}\text { 0. } 1283 \\
1.78\end{array}$ & NORMALIZED PLANT BIOMASS & & \\
\hline
\end{tabular}

Fig. 1. Entry means of biomass production and partitioning in wet and dry treatments for the period 14 to 51 days post-emergence. Entries not marked with a common letter are significantly different $(\mathbf{P}<0.05)$.

Although there were some notable changes in rank among entries between treatments (changes in position $>3$ : Caddo switchgrass, WW-442, WW-604, WW-765, WW-811), the significant and posi- tive Spearman coefficient $\left(r_{2}=0.53, P<0.01\right)$ indicates a similarity among entry ranks between treatments. Except for Bca (dry), the Old World bluestem group means exceeded that of the natives regardless of watering regime (Table 3 ). Dry treatment production averaged about 0.58 (range $=0.36$ to 0.71 ) of the wet treament across all entries with the native, Bin, and Bis groups reacting quite similarly to water stress (mean dry/wet $=0.6$ ). However, the ratio for Bca was less than 0.4, which is consistent with other results showing that Caucasian bluestem maintained its production potential poorly under water stress (Coyne et al. 1982).

Field trials conducted in the late 1950's at Woodward, Okla., showed that Caucasian bluestem, blue grama, and sideoats grama (Bouteloua curtipendula) had poor scedling vigor comparcd to switchgrass, sand bluestem, weeping lovegrass (Eragrostis curvula), and sand lovegrass (E. trichodes) (E.H. Mcllvain and M.C. Shoop, unpublished data). These data on relative performance of Caucasian bluestem are in apparent agreement with results of the present study. In addition, previous la boratory (Coyne et al. 1982) and field (Coyne and Bradford 1985) comparisons of WW-765 (Bca) and WW-Spar (Bis) are in agreement in that WW-765 out yielded WW-Spar under optimal conditions, but rapidly lost its performance advantage under stress. WW-Spar was shown to be less able to take advantage of high soil moisture, but maintained performance closer to its potential under stress than did WW-765 in these earlier studies.

Like Caucasian bluestem, blue grama was found by Mcllvain and Shoop to have low seedling vigor. Although blue grama in this study ranked low in biomass production, it maintained its production well under water stress (dry/wet $=0.71$; highest of all entries). Low seedling vigor in blue grama is apparently related to its morphology (Wilson et al. 1976, Briske and Wilson 1977) and its short-lived seminal root. Very soon after emergence, it becomes dependent upon adventitious roots which may develop as early as 11 days after planting (Briske and Wilson 1977) providing the soil surface remains moist for 2-3 days. In our study, the soil surface was kept moist during this critical post-emergence period, allowing adventitious roots to become established before water was withheld, which may explain its high production under water stress compared to the wet treatment.

Partitioning among 3 tissue frations was remarkably uniform across entries and relatively insensitive to water stress (Fig. 1). Mean partitioning coefficients were 0.36:0.29:0.35 for roots:sheaths plus stems:leaf blades. The native, and Bca groups partitioned about 0.7 of their total biomass aboveground while the Bin and Bis groups partitioned significantly less to aboveground tissues (Ws/Wp, Wet;Table 3). The native species tended to be more leafy than the Old World bluestems in that they partitioned a greater portion of their aboveground biomass to leaf blades and less to sheaths plus stems (Wb/Ws, Table 3). Treatment means showed that water stress did not greatly affect leafiness or shoot:root ratios and entry ranks were similar for both treatments $\left(r_{\mathrm{s}}=0.67\right.$ for $\mathrm{Wb} / \mathrm{Ws}, 0.75$ for Ws $/ W p ; P<0.01)$. The relative insensitivity of shoot:root to water stress is surprising since root growth is commonly favored over shoot growth under water stress conditions (Hsiao and Acevedo 1974).

\section{Morphological Parameters}

Tillering varied significantly among entries and for most entries this parameter was negatively affected by water stress (Fig. 2). Exceptions were WW-517, WW-535, WW-604, and WW-822 which had more tillers when grown under water stress. The Old World bluestems produced more tillers/plant than the natives (Table 3). Within the Old World bluestems, the Bca group had fewer tillers than Bis (wet and dry) and Bin (dry). This is consistent with field data (unpublished) on crown diameters of WW-Spar (Bis) and WW-765 (Bca) which averaged $187 \pm 26$ and $145 \pm 24 \mathrm{~mm}$, respectively. The sensitivity of the 2 Caucasian bluestems and WW-886 to water stress was especially pronounced with tiller 


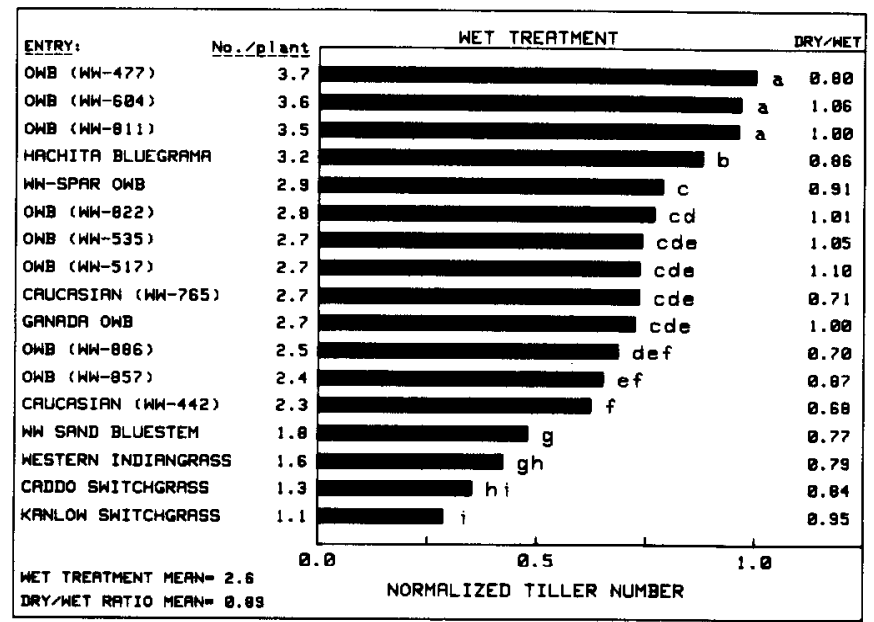

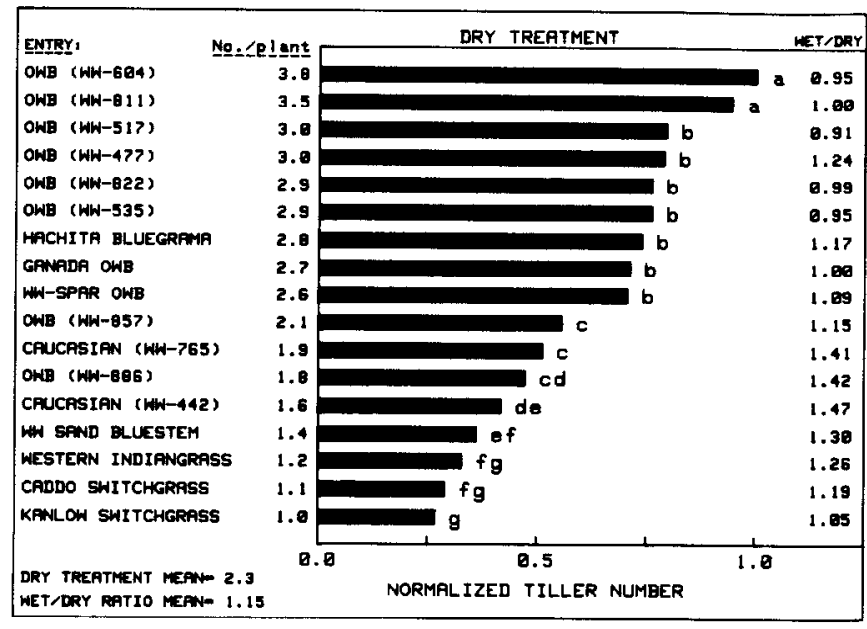

Fig. 2. Entry means of tiller number in wet and dry treatments for the period 14 to 51 days post-emergence. Entries not marked with a common letter are significantly different $(\mathrm{P}<0.05)$.

number being reduced $29-32 \%$ by the dry treatment. Overall, entry rank did not change appreciably between treatments $\left(r_{\mathrm{B}}=0.89\right.$, $P<0.01$ ). Rank position of only 2 entries (WW-517, WW-Spar) changed by more than 3 .

The number of leaves/plant varied about four-fold among entries (Fig. 3) and, not surprisingly, the entry ranks were very similar to that for tiller number $\left(r_{8}=0.98, P<0.01\right)$. Entry rank for leaf number $\left(r_{\mathrm{s}}=0.94, P<0.01\right)$ was less sensitive to water stress than for tiller number. Only WW-477 changed rank by more than 3 positions between wet and dry treatments. Water stress had a greater negative effect on leaf number than on tiller number so that the average leaves/tiller was reduced from 3.63 to 3.28 by the dry treatment (Table 3). Leaves/tiller was most affected by water stress in the Bin and Bis groups.

Total leaf area/plant was also quite variable among entries and very sensitive to water stress which reduced mean area for all entries by $43 \%$ (Fig. 4). Four entries (Caddo switchgrass, WW-442, WW-Spar, WW-765) changed rank by more than 3 positions under water stress $\left(r_{s}=0.58, P<0.05\right)$. In these 4 , leaf area was reduced over $50 \%$ by water stress. Leaf area in the other entries was less sensitive to withholding water, but even the least sensitive (Caddo switchgrass) lost $26 \%$ of its leaf area in the dry treatment. The Old World bluestem species had more tillers, more leaves, and more leaf area per plant than the native group, but the natives had

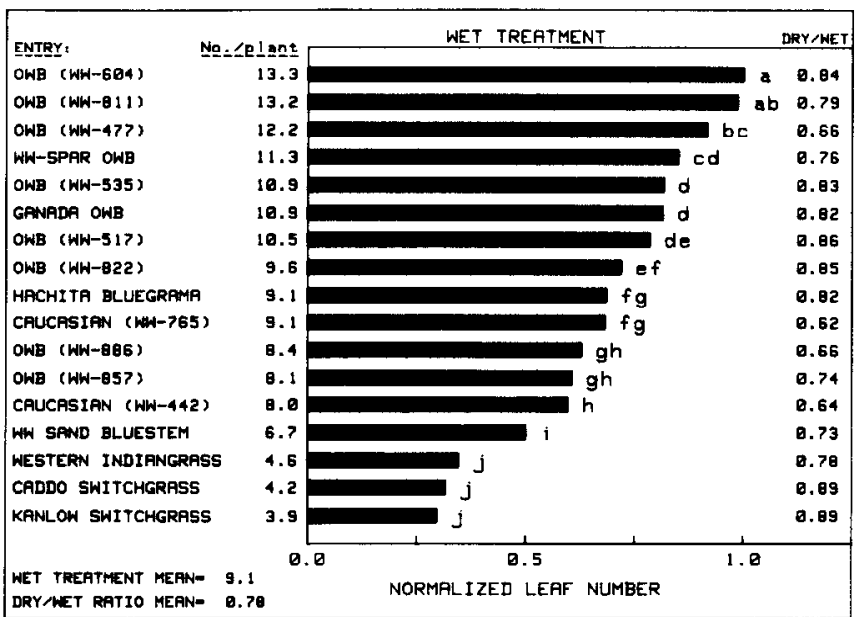

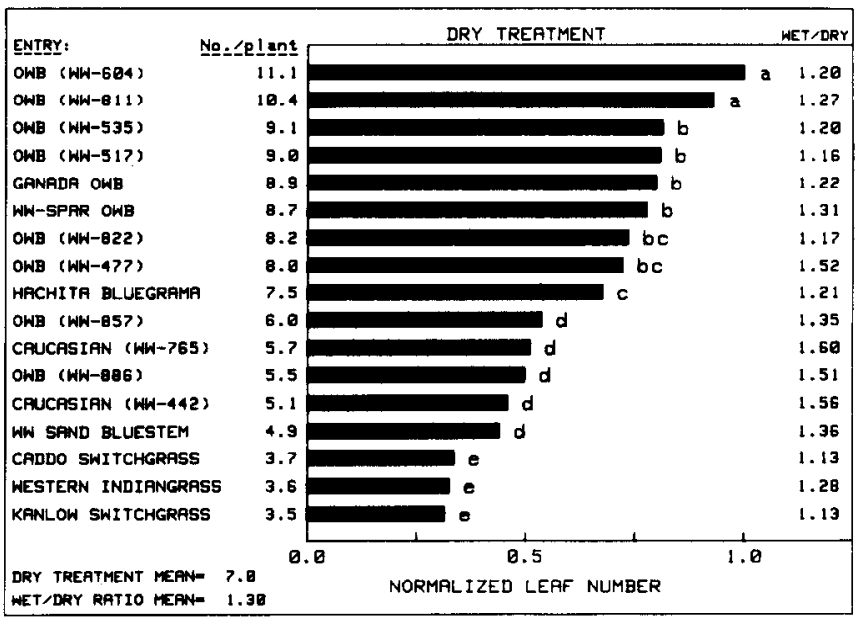

Fig. 3. Entry means of leaf number in wet and dry treatments for the period 14 to 51 days post-emergence. Entries not marked with a common letter are significantly different $(\mathrm{P}<0.05)$.

larger leaves than the Old World bluestems (Table 3). Leaf size was reduced in all groups by water stress, but entry ranks were essentially unchanged $\left(r_{\mathrm{s}}=0.95, P<0.01\right)$.

Extended height of these grasses varied by about a factor of 2 and on the average was reduced about $22 \%$ by the dry treatment (Fig. 5) compared to $40-50 \%$ for biomass production. Similarly to biomass production, the 2 Caucasian bluestems were reduced most in height by water stress. Although the native group was found to produce fewer leaves and tillers than the Old World bluestems, it had greater height growth than the Bis (wet, dry) and Bca (dry) groups (Table 3 ) and height of the natives was least affected by water stress. Blue grama was in a height class by itself in both treatments (Fig. 5). Its growth form under the experimental conditions appeared atypical of field-grown plants. Its leaves were long and narrow and only indiangrass equaled its allocation of aboveground biomass to leaf blades $(65 \%)$. Although water stress significantly reduced height growth, entry rank within treatments was very similar $\left(r_{\mathrm{a}}=0.90, P<0.01\right)$.

Specific leaf weight is an index of biochemical costs and can be thought of in terms of the biomass required to build a unit area of leaf tissue. Biomass investment in leaf tissue varied by about a factor of 2 and the native species occupied the first 5 rank positions in the dry treatment and were included in the first 6 positions of the wet treatment (Fig. 6). For the entry groups, specific leaf weight of 


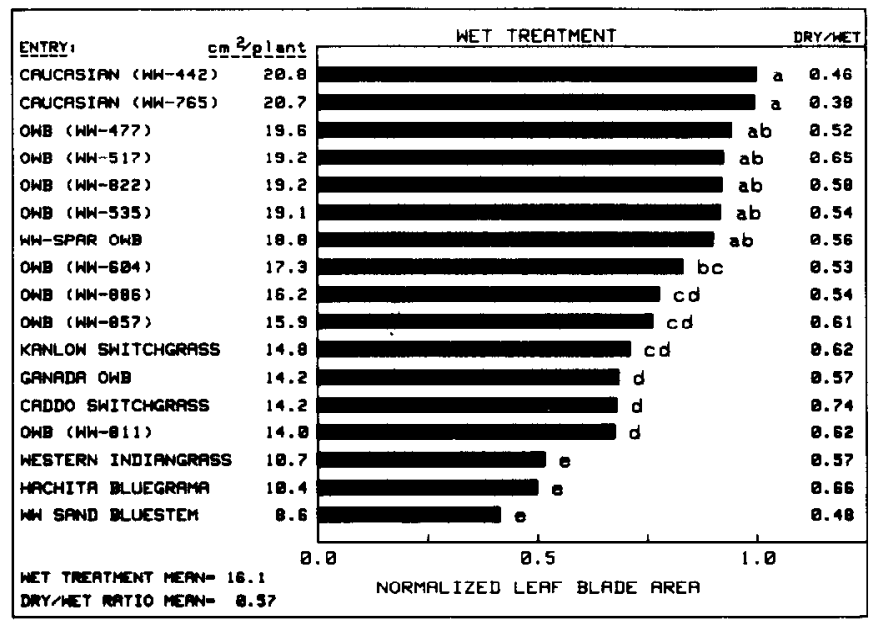

\section{ENIRY:}

HACHITA BLUEGRAMA

KFANLWW SWITCHGRASS

CPDDO SWITCHGRASS

OWB (WW-BE2)

CAUCASIAN (WW-765)

CAUCASIAN (WW-442)

OWB (WW-5:?)

OWB (WW-535)

OWB (WH-886)

OWB (WW-85?)

WESTERN INDIANGRASS

WW-SPAR OWB

GANADF OWB

OWB (WW-6B4)

OWB (WW-4??)

WW SAND BLUESTEM

OWB (WH-811)

NET TREATMENT MEAN- 24.1 DRY/HET RATIO MEAN- 0.76

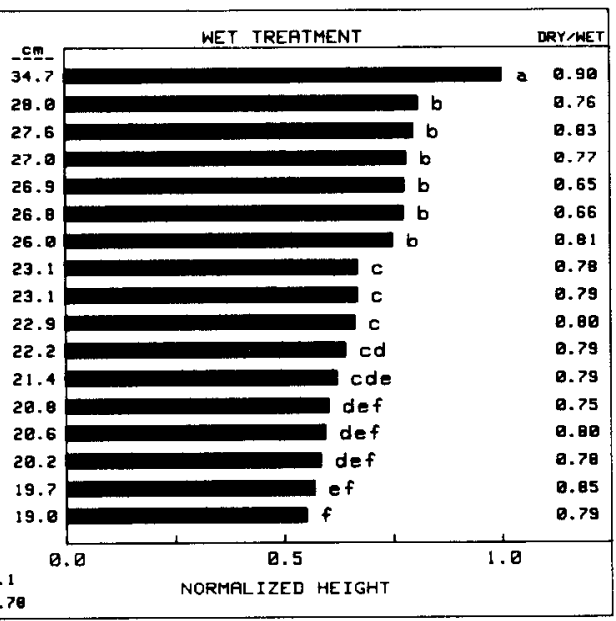

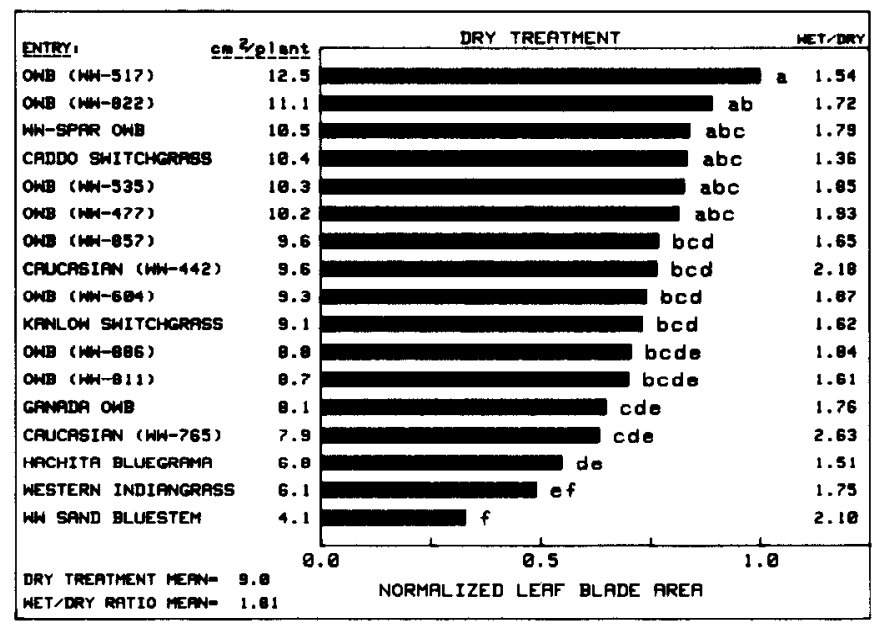

Fig. 4. Entry means of leaf blade area in wet and dry treatments for the period 14 to 51 days post-emergence. Entries not marked with a common letter are significantly different $(\mathrm{P}<0.05)$.
ENTEY:

HACHITA BLUEGRAMP

CADDO SWITCHGRASS

KANLOW SWITCHGRASS

OWB (WW-517)

OWB (WW-822)

OWB (WH-857)

OWB (WW-886)

OWB (WW-535)

CAUCASIAN ( $W W-442$ )

CRUCASIAN (WW-765)

WESTERN INDIANGRASS

WH-SPAR OWB

WW SAND BLUESTEM

OWB (WN-694)

OWB (WW-477)

GANADR OWB

OWB (WW-8:1)

DRY TREFTMENT MERN- 10. HET/DRY RATIO MEAN- 1.28

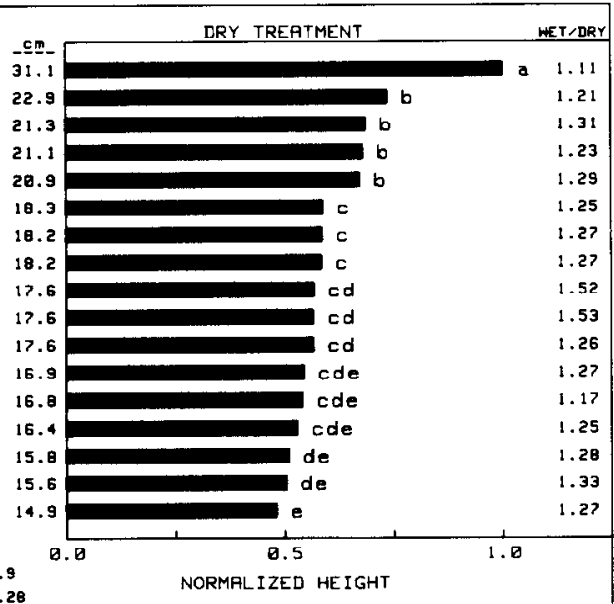

Table 4. Entry group means for selected growth parameters.

Fig. 5. Entry means of extended height in wet and dry treatments for the period 14 to 51 days post-emergence. Entries not marked with a common letter are significantly different $(P<0.05)$.

\begin{tabular}{|c|c|c|c|c|c|c|}
\hline \multirow[b]{2}{*}{ Parameter $<1>$} & \multirow[b]{2}{*}{ Treat. } & \multicolumn{4}{|c|}{$<---1-3-$ Entry Groups } & \multirow{2}{*}{$\begin{array}{c}\text { Grand } \\
\text { mean }<3>\end{array}$} \\
\hline & & Native $<2>$ & B. caucasica & B. intermedia & B. ischaemum & \\
\hline $\begin{array}{l}\text { RGR of shoot } \\
\text { biomass, Rs } \\
\left(\mathrm{g} \mathrm{g}^{-1} \mathrm{~d}^{-1}\right)\end{array}$ & $\begin{array}{c}\text { Wet } \\
\text { Dry } \\
\text { Dry/Wet }\end{array}$ & $\begin{array}{c}0.133 \\
0.121 \\
0.91\end{array}$ & $\begin{array}{c}0.160 \\
0.154 \\
0.96\end{array}$ & $\begin{array}{c}0.150 \\
0.127 \\
0.85\end{array}$ & $\begin{array}{c}0.138 \\
0.123 \\
0.89\end{array}$ & $\begin{array}{l}0.144 \\
0.124 \\
0.86\end{array}$ \\
\hline $\begin{array}{l}\text { RGR of root } \\
\text { biomass, } R r \\
\left(\mathrm{~g} \mathrm{~g}^{-1} \mathrm{~d}^{-1}\right)\end{array}$ & $\begin{array}{c}\text { Wet } \\
\text { Dry } \\
\text { Dry/Wet }\end{array}$ & $\begin{array}{c}0.151 \\
0.140 \\
0.92\end{array}$ & $\begin{array}{c}0.175 \\
0.165 \\
0.94\end{array}$ & $\begin{array}{c}0.166 \\
0.144 \\
0.87\end{array}$ & $\begin{array}{c}0.161 \\
0.142 \\
0.88\end{array}$ & $\begin{array}{l}0.162 \\
0.145 \\
0.89\end{array}$ \\
\hline $\begin{array}{l}\text { RGR of total } \\
\text { plant biomass, } \\
\operatorname{Rp}\left(\mathrm{g} \mathrm{g}^{-1} \mathrm{~d}^{-1}\right)\end{array}$ & $\begin{array}{c}\text { Wet } \\
\text { Dry } \\
\text { Dry/Wet }\end{array}$ & $\begin{array}{c}0.138 \\
0.126 \\
0.91\end{array}$ & $\begin{array}{c}0.164 \\
0.155 \\
0.95\end{array}$ & $\begin{array}{c}0.155 \\
0.132 \\
0.85\end{array}$ & $\begin{array}{c}0.145 \\
0.128 \\
0.88\end{array}$ & $\begin{array}{c}0.149 \\
0.133 \\
0.89\end{array}$ \\
\hline $\begin{array}{l}\text { RGR of leaf } \\
\text { blade area, } \\
R b\left(m^{2} m^{-2} d^{-1}\right)\end{array}$ & $\begin{array}{c}\text { Wet } \\
\text { Dry } \\
\text { Dry/Wet }\end{array}$ & $\begin{array}{l}0.111 \\
0.090 \\
0.81\end{array}$ & $\begin{array}{l}0.127 \\
0.120 \\
0.95\end{array}$ & $\begin{array}{l}0.119 \\
0.096 \\
0.80\end{array}$ & $\begin{array}{l}0.119 \\
0.088 \\
0.74\end{array}$ & $\begin{array}{l}0.119 \\
0.095 \\
0.80\end{array}$ \\
\hline $\begin{array}{l}\text { Leaf area } \\
\text { ratio, } \mathrm{F} \\
\left(\mathrm{m}^{2} \mathrm{~kg}^{-1}\right)\end{array}$ & $\begin{array}{c}\text { Wet } \\
\text { Dry } \\
\text { Dry/Wet }\end{array}$ & $\begin{array}{r}10.45 \\
8.88 \\
0.85\end{array}$ & $\begin{array}{r}13.32 \\
11.02 \\
0.83\end{array}$ & $\begin{array}{r}12.01 \\
9.44 \\
0.79\end{array}$ & $\begin{array}{r}12.18 \\
9.73 \\
0.80\end{array}$ & $\begin{array}{r}11.72 \\
9.49 \\
0.81\end{array}$ \\
\hline $\begin{array}{l}\text { Unit leaf } \\
\text { rate, Eb } \\
\left(\mathrm{g} \mathrm{m}^{-2} \mathrm{~d}^{-1}\right)\end{array}$ & $\begin{array}{c}\text { Wet } \\
\text { Dry } \\
\text { Dry/Wet }\end{array}$ & $\begin{array}{r}12.94 \\
13.72 \\
1.06\end{array}$ & $\begin{array}{r}11.67 \\
13.40 \\
1.15\end{array}$ & $\begin{array}{r}12.38 \\
13.49 \\
1.09\end{array}$ & $\begin{array}{r}11.38 \\
12.52 \\
1.10\end{array}$ & $\begin{array}{r}12.38 \\
13.44 \\
1.09\end{array}$ \\
\hline
\end{tabular}

$<$ I $>$ RGR=relative growth rate.

$<2>$ The native group means included only the four tall grasses and not blue grama.

$<3>$ The grand means included all 17 entries. 


\section{ENTRY:}

HACMITR BLUEGRAMA

WW SAND BLUESTEM

CADDO SWITCHCRASS

KANLOH SWITCHGRASS

OWB (NW-822)

WESTCRN INOIANCRASS

OWB (WW-8B5)

OWB $(W W-4) ?$

OWB (WW-85)

CAUCASIAN (WH-765)

OWB (WW-535)

OWB $(N W-51)$

OWB (WW-O1)

CAUCASIAN (WN-442)

UWD (WW-684)

GANADA OWB

WW-SPAR OWB

WET -REAT MENT MERNE 17.2

DRY.WET RATIO MEAN- 1.0

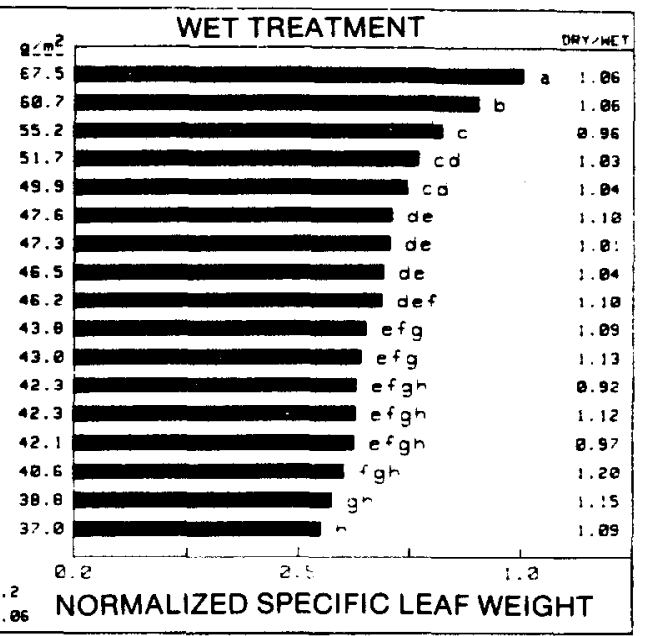

NORMALIZED SPECIFIC LEAF WEIGHT
ENIRE:

HACHITA GLUEGRAMA

W SAND BLUESTEM

KANLOW SWITCHGRASS

CADCO SWITCHGRPSS

HESTERH INDIANGRASS

ONA (Ha-625:

OWB (WW-ES?)

OWB (WW-6BA)

OWB (WW-535)

Uine (wn-4)?

ONB (wm-8B5)

CQUCASIAN (WW-755)

OWB (WW-B1:)

GANADG OWE

GAUCASIAN (WW-442)

WW-SPAR OWE

OWB (mw-5:?)

DRe tREATMENT MEANE 58.0 WET/DRY RRTIO MEAN-

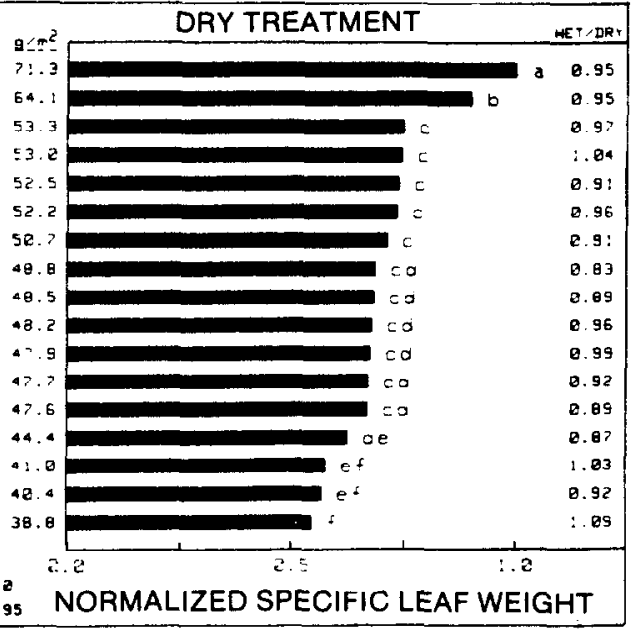

Fig. 6. Entry means of specific leaf weight in wet and dry treatments for the period 14 to 51 days post-emergence. Entries not marked with a common letter are significantly different $(\mathrm{P}<0.05)$.

the native species was significantly greater than all of the Old World bluestem groups regardless of treatment (Table 3). Among the Old World bluestem groups, there was a slight separation in the wet treatment, but there were no significant differences in the dry treatment. Reduced watering resulted in an increase in specific leaf weight in all entries except Caddo switchgrass, WW-517, and WW-442. Across all entries, specific leaf weight increased $6 \%$. There was, however, a disparity among groups in response of specific leaf weight to water stress. Specific leaf weight in the native, Bca, and Bin groups increased by only 3 to $4 \%$ (not significant) compared to $12 \%$ in the Bis group. Thus, although leaf area was reduced by water stress, specific leaf weight increased, a pattern also observed in cereals (Rawson et al. 1977). Treatment effects did not alter entry ranking appreciably $\left(r_{\mathrm{a}}=0.86, P<0.01\right)$. Entries WW-517, WW-604, and WW-886 changed in rank by more than 3 positions.

A basic difference in resource allocation pattern emerges from these data. The native species tended to produce a few expensive leaves compared to the Old World bluestem species. The Old World bluestems exhibited considerable variation within and between species groups in both leaf number and specific leaf weight, but on the whole, their allocation pattern appeared to more
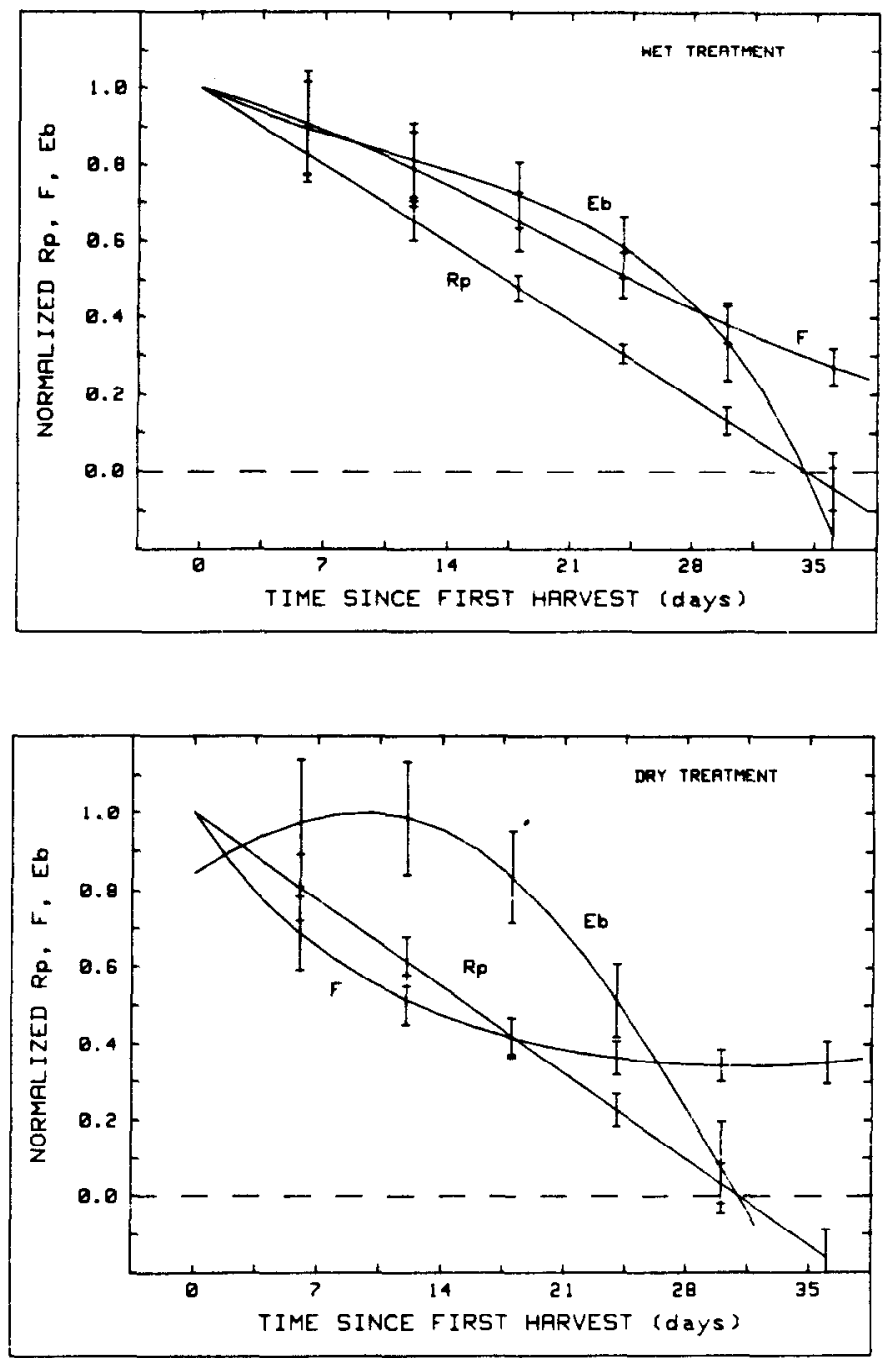

Fig. 7. Time course of normalized means across ent ries for relative growth rate of total plant biomass $(R p)$, leaf area ratio $(F)$, and unit leaf rate $(E b)$ in the wet and dry treatments for the period 14 to 51 days post emergence.

closely resemble one that is conducive to maximizing the capture of light energy than that of the natives. The Old World bluestems, as a group, rapidly produced a leaf canopy composed of numerous yet relatively cheap leaves. This behavior should be advantageous not only for seedling establishment, but for defoliation tolerance as well. Caldwell et al. (1981) found that a grazing-tolerant Agropyron bunchgrass had a lower investment of nitrogen and biomass per unit area of photosynthetic tissue than a less tolerant one. In an earlier study (Coyne and Bradford 1985), growth dynamics of WW-Spar, WW-535, WW-604 (all in the Bis group and components of Plains bluestem), and WW-758 (another Caucasian bluestem similar to WW-765) were compared in the field. Under conditions of adequate soil moisture as well as drought stress, these accessions ranked as WW-604>WW-535>WW-758>WW-Spar for both biomass and nitrogen per unit leaf area. In the dry treatment of the present study, the entry ranks for specific leaf weight (WW-604>WW-535>WW-765>WW-442>WW-Spar) were comparable to that of the field study. Both studies indicate considerable latitude exists to select for a pattern of resource allocation that maximizes canopy development within and among the Old World bluestem entry groups.

Assuming that seedling vigor is associated with high numbers of tillers and leaves, high leaf area, and low biomass investment per unit of leaf area, then a composite rank index can be derived from 
the individual parameter ranks. Using these criteria, seedling vigor could be expected to be greatest in the Bis group followed by Bin>Bca $>$ Native.

\section{Growth Parameters}

Relative growth rate of biomass or leaf area describes growth in terms of the return on biomass or area invested, respectively. Because all absolute growth rate curves were fit with second order equations, the relative rates were linear functions of time with maximum values at $t=0$ (intercept). Intercepts of the relative growth parameters ( $R p, R b)$ ranged from about 0.2 to 0.3 in the wet treatment. The dry treatment had little effect on the intercept of $R p$ averaged across all entries since water stress effects were minimal at the first harvest. Nevertheless, the average intercept for $\mathrm{Rb}$ in the dry treatment was reduced to 0.73 of the wet treatment value, suggesting a greater sensitivity to water stress for $R b$ than for $R p$. Variability among entries within groups was greater for the growth than for the morphological parameters, resulting in fewer significant differences among entries. In addition, entry rank changed more between treatments $\left(r_{\mathrm{g}}=0.22\right.$ and 0.12 for the intercepts of $R p$ and $R b$, respectively, $P<0.05$ ) than for the morphological parameters. Thus, individual entry data for the growth parameters will not be referenced in the remaining discussion.

High relative growth rates are not necessarily desirable traits with respect to performance maintenance under stress. Grime and Hunt (1974) surveyed 132 species of monocots and dicots from a diversity of habitats under controlled and uniform conditions and observed a low frequency of potentially fast-growing species in unproductive habitats and stated that genetic characteristics conducive to rapid growth in productive conditions possibly become disadvantageous when plants are subjected to environmental stress. In our study, the correlation between intercepts and absolute slopes ranged from 0.92 to $0.97(P<0.01)$ depending on the parameter ( $R s, R r, R p, R b)$ showing that entries with the highest growth efficiencies at the start of sampling also were the ones which had the greatest decline in efficiency with time regardless of treatment. Therefore, integrating the area under the growth parameter curves may be a better way to compare growth efficiency among entries differing in both intercepts and slopes. Means for each entry group were calculated for the period 0 to 28 days (Table 4). Means were not separated statistically since individual growth curves were fit across rather than within replicates. The upper integration limit was set at 28 days because relative rates became negative at about this time. Also, the first few weeks post emergence would seem most important if early growth rate is a determinant of competitive advantage.

Mean relative growth rates of biomass and leaf area were generally highest in the Bca group and lowest in the native group (Table 4). The Bin and Bis groups were intermediate. The growth efficiency of roots exceeded that of shoots in all groups and both treatments (average $\mathrm{Rr} / \mathrm{Rs}=1.14$ ) and, like Ws/Wp (Table 3), this ratio was essentially unaffected by water stress. Regardless of treatment, the growth efficiency of total plant biomass (Rp) exceeded that of leaf blade area ( $R b)$ and, except for the Bca group, water stress reduced $R b$ more the $R p$ so that the ratio $(R b / R p)$ also decreased.

Dry matter production depends on both the amount of leaf area per plant (morphology) and the assimilation rate per unit leaf area (physiology). The interaction between leaf area and photosynthetic rate can be analyzed by dividing $R p$ into its component determinants, $\mathrm{F}$ and $\mathrm{Eb}$ (Kriedemann and Barrs 1983). $\mathrm{F}$ is a morphological index of plant growth relating leaf area to total plant biomass. $\mathrm{Eb}$ is a physiological index relating the rate of increase of dry weight of the whole plant to unit leaf area and it is closely connected to photosynthetic activity (Evans 1972). Evans stated that both indices have their own ontogenetic drift that is quite different in form. Whether reductions in $\mathrm{Rp}$ due to recurring cycles of short-term drought are primarily attributable to reductions in $F$ or Eb is evidently species dependent; but restriction of leaf expansion, which lowers $F$, is apparently the more common cause of reductions in Rp even during mild water stress. (Kriedemann and Barrs 1983).

Integrated means for $\mathrm{Rp}$ and its components, $\mathrm{F}$ and $\mathrm{Eb}$ (Table 4), show that water stress reduced $F$ in all entry groups and generally resulted in an increase in the efficiency of production of new biomass from existing leaf blade area as measured by Eb. These results agree with the conclusions of Kriedemann and Barrs (1983) that $\mathbf{F}$ was the more important determinant of reductions in $\mathbf{R p}_{\mathbf{p}}$ due to limited soil water. However, this conclusion must be qualified with a time reference as shown below.

Because trends in $\mathrm{Rp}, \mathrm{F}$, and $\mathrm{Eb}$ with time were similar in all entries, an average, normalized graph was constructed to show the time relationships among these parameters (Fig. 7). All three variates declined throughout the sampling period in the wet treatment, but $\mathrm{Eb}$ increased during the first 2 weeks of sampling in the dry treatment. F declined in near linear fashion in the wet treatment. In the dry treatment, $F$ showed an accelerated decline during the period $\mathrm{Eb}$ was increasing and then leveled off as reductions in $\mathrm{Eb}$ became the dominant influence on $\mathrm{Rp}$. Thus, early in the cyclical water stress treatment, $F$ predominated in effecting reductions in $\mathrm{Rp}$ while Eb predominated more as stress symptoms accumulated; i.e., reduction in carbon allocation to leaf area was initially the main cause of a drop in Rp, but ultimately, the efficiency with which the standing crop of leaf area was producing new dry matter was the controlling influence on $R p$. Differences in ontogenetic drift for $F$ and Eb noted by Evans (1972) were amplified by water stress in these 17 grasses.

If $\mathrm{F}$ is more important than $\mathrm{Eb}$ in determining reductions in $\mathrm{Rp}$ due to water stress, then ranking the entries by the correlation coefficient of Rp:F for the dry treatment might be expected to array the entries by drought sensitivity, i.e., entries having low $r$ values (less dependent on F) should be least susceptible to withholding water. We certainly do not have comparative field data on all entries for the same conditions, but some patterns do emerge from this ranking that appear to correspond to relative drought performance. For example, the $r$ values suggest that WW-Spar is superior to WW-477, WW-604, and WW-765 (respective $r$ values $=0.80,0.84,0.92,0.96$ ), which agrees with rankings from another study (Coyne et al. 1982). WW-811 had the lowest $r(0.78)$ of all entries and the $r$ for WW-442 (0.90) was less than that of WW-765 (0.96). Field qualitative ratings of plant introduction nurseries at Woodward show that WW-811 remained green longer into drought cycles than 300 other $B$. intermedia and $B$. ischaemum accessions and that WW-442 was superior to WW-765 in drought performance (C.L. Dewald, pers. comm.).

Water stress had opposite effects on the slopes of $R p$ and $R b$. For $R p$, the average slope became more negative (dry/wet $=1.09$, $r_{s}=0.16$ ), but the slope of Rb became less negative (dry/wet $=0.67$, $r_{\mathrm{s}}=-0.18$ ). The nonsignificant Spearman coefficients show dissimilar entry ranks between treatments.

In order for $R p$ and $R b$ to be equal over a given time interval, $F$ must remain constant, indicating the plant is multiplying units of structure all having the same ratio of leaf area to plant dry weight (Evans 1972). When $F$ is increasing, $R b>R p$ and conversely. The cross-over point where $R p=R b$ should mark a change in allocation pattern. The point of equality of $R p$ and $R b$ was negative in the wet treatment indicating $\mathrm{Rp}>\mathrm{Rb}$ throughout the sampling period and confirming that $F$ decreased approximately linearly throughout this period in all entries (Fig. 7). In the dry treatment, the crossover was positive for all entries and averaged about 35 days (range $=26$ to 59 ) with $\mathrm{Rp}>\mathrm{Rb}$ prior to the point of equality. In the dry treatment, $F$ declined rather steeply from the first through the third harvest dates and then declined more gradually up to the cross-over date (Fig. 7). Beyond the cross-over, F began to gradually increase and $R \mathbf{b}>\mathrm{R}$ p so that the partitioning was favoring leaf area over supporting structures.

The significance of differences in cross-over time to relative 
drought performance among these grasses was not readily apparent from our data. Although entry groups showed some mean differences in this parameter under water stress (natives $=35$, $B c a=46, B i n=29, B i s=35$ ), the within group viability was high. The tendency for $F$ to reverse its normal ontogenetic decline in the dry treatment as water stress effects became increasingly severe during the last half of the sampling period would seem counter productive if the ratio of transpiring surface to absorbing root surface were increased. We have no measure of effective root surface area, but ratios of $\mathrm{Ab} / \mathrm{Wr}$ increased in most entries between 35 and 42 days post emergence (entry mean increased from 5.8 to $7.0 \mathrm{~m}^{2} \mathrm{~kg}^{-1}$ ). However, this increase in $\mathrm{Ab} / \mathrm{Wr}$ was accompanied by a reduction in specific leaf weight (entry mean decreased from 68 to $57 \mathrm{~g} \mathrm{~m}^{-2}$ ) while leaf weight ratio $(\mathrm{Wb} / \mathrm{Wp})$ remained constant. Therefore, the increase in leaf area in relation to biomass was accomplished by building cheaper leaves. Whether or not this growth behavior is an appropriate response to water stress depends upon how the $\mathrm{CO}_{2}$ diffusion pathway is configured. Increasing the size of the photosynthetic canopy would lead to more efficient light energy capture and could be beneficial if residual conductance for $\mathrm{CO}_{2}$ increased relative to stomatal conductance. Under these conditions, the plant may achieve an increase in water-use efficiency without amplifying the internal water deficit.

Assuming that identification of appropriate screening parameters would benefit efforts to enhance seedling vigor in forage grass germplasm, the usefulness of a particular parameter might be predicted on the basis of its relative sensitivity to water stress and its Spearman's coefficient. A parameter with a negative or low positive Spearman's coefficient (entry ranking changes significantly under stress) should better delineate superior stress performance than parameters with high positive coefficients. Parameters with high sensitivity to water stress would be desirable since the required accuracy of the measurements would be less than for parameters of low stress sensitivity. Using these criteria, both total plant biomass and total leaf blade area would rank high as potential screening parameters among the set tested in this study.

\section{Literature Cited}

Briske, D.D., and A.M. Wilson. 1977. Temperature effects on adventitious root development in blue grama seedlings. J. Range Manage. 30:276-280.

Caldwell, M.M., J.H. Richards, D.A. Johnson, R.S. Nowak, and R.S. Dzurec. 1981. Coping with herbivory - photosynthetic capacity and resource allocation in two semiarid Agropyron bunchgrasses. Oecologia 50:14-24.

Coyne, P.I., and J.A. Bradford. 1985. Some growth characteristics of four Old World bluestems. J. Range Manage. 38:27-33.

Coyne, P.I., J.A. Bradford, and C.L. Dewald. 1982. Leaf water relations and gas exchange in relation to forage production in four Asiatic bluestems. Crop Sci. 22:1036-1040.

Davies, W. 1967. Seeds mixture problem. Welsh Plant Breed. Sta. Bull. Ser. H. 6:39-63.

Duncan, D.B. 1955. Multiple range and multiple F tests. Biometrics 11:1-42.

Evans, G.C. 1972. The quantitative analysis of plant growth. Studies in Ecology. Vol. I. University of California Press, Berkeley.

Grime, J.P., and R. Hunt. 1975. Relative growth-rate: its range and adaptive significance in a local flora. J. Ecol. 63:393-422.

Harlan, J.R., R.P. Celarier, W.L. Richardson, M.H. Brooks, and K.L. Mehra. 1958. Studies on Old World bluestems. II. Oklahoma Agr. Exp. Sta. Tech. Bull. No. T-72, Stillwater.

Hsiao, T.C., and E. Acevedo. 1974. Plant responses to water deficits, water-use efficiency and drought resistance. Agr. Meteorol. 14:59-84.

Hunt, R., and I.T. Parsons. 1974. A computer program for deriving growth-functions in plant growth analysis. J. Appl. Ecol. 11:297-307.

Hunt, R., and 1.T. Parsons. 1981. Plant growth analysis. Users'inst ructions for the stepwise and spline programs. Natural Environment Research Council, Unit of Comparative Plant Ecology, University of Sheffield, Sheffield.

Johnson, D.A. 1984. Improved rangeland species: a physiological perspective. Proc. Int. Rangeland Cong., May 13-18, Adelaide, Australia. (in press).
Kneebone, W.R. 1972. Breeding for seedling vigor, p. 90-100. In: V.B. Younger and C.M. McKell [eds.] The Biology and Utilization of Grasses. Academic Press, New York.

Kriedemann, P.E., and H.D. Barrs. 1983. Photosynthetic adaptation to water stress and implications for drought resistance, p. 201-230. In: C.D. Raper, Jr., and P.J. Kramer [eds.] Crop Reactions to Water and Temperature Stresses in Humid, Temperate Climates. Westview Press, Boulder, Colo.

McKell, C.M. 1972. Seedling vigor and seedling establishment, p. 74-89. In: V.B. Youngner and C.M. McKell [eds.] The Biology and Utilization of Grasses. Academic Press, New York.

Rawson, H.M., A.K. Bagga, and P.M. Bremmer. 1977. Aspects of adaptation by wheat and barley to soil moisture deficits. Aust. J. Plant Physiol. 4:389-401.

Satterthwaite, F.W. 1946. An approximate distribution of estimates of various components. Biom. Bull. 2:110-114.

Sims, P.L., and C.L. Dewald. 1982. Old World bluestems and their forage potential for the Southern Great Plains. A review of early studies. USDA Agr. Res. Serv., Agr. Rev. and Man., Southern Series, ARM-S-28, Southern Regional office, New Orleans.

Steel, R.G.D., and J.H. Torrie. 1980. Principles and procedures of statistics. 2nd Ed. McGraw-Hill Book Co., New York.

Taliaferro, C.M., J.R. Harlan, and W.L. Richardson. 1972. Plains bluestem. Oklahoma Agr. Exp. Sta. Bull. B-699. Stillwater.

Vallentine, J.F. 1980. Range development and improvements. 2nd Ed. Brigham Young University Press, Provo, Utah.

Whalley, R.D.B., and C.M. McKell. 1973. Techniques for assessing seedling vigor and establishment and potential application in breeding programs in grasses. Proc. Scotts Turfgrass Res. Conf. 4:33-56.

Wilson, A.M., D.N. Hyder, and D.D. Briske. 1976. Drought resistance characteristics of blue grama seedlings. Agron. J. 68:479-484.

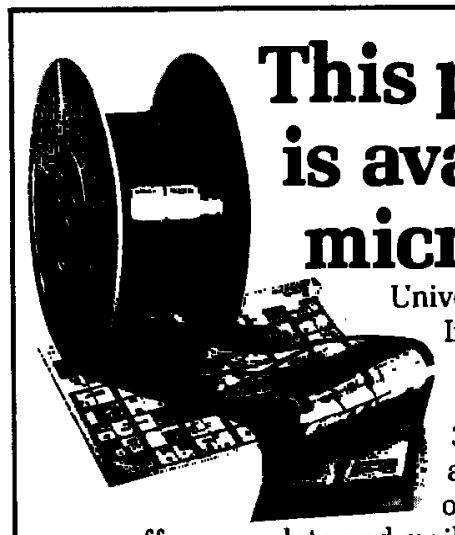

publication ailable in we offer, complete and mail the coupon to: University Microfilms International, 300 N. Zeeb Road, Ann Arbor, MI 48106. Call us toll-free for an immediate response: 800-521-3044. Or call collect in Michigan, Alaska and Huwaii: 313-761-4700.

$\square$ Please send information about these titles:

Name

Company/Institution

Address

City

State Zip

Phone!

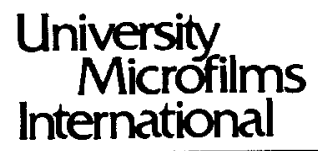

